\title{
De-Centering Lamentations: A Crisis of Hope, of Memory, and of Continued Presence
}

\author{
Scott Ellington (EMmanuel College)
}

\begin{abstract}
Scholars have frequently looked to chapter three at the centre of the book of Lamentations to provide a note of hope, faith, and comfort, so that the book as a whole is considered a chiasm with its resolution at the centre. But this does not give adequate attention to the developing story line running through the book as a whole or the role that chapter three plays in heightening the crisis initiated by the exile and provoking a turning point in the story. The arc of the story told by a variety of characters reaches its climax in chapter three and the forward movement of the story can be seen in the move from dirge to lament and from isolation to community as Israel considers the ways in which their relationship with Yahweh has fundamentally changed.
\end{abstract}

KEYWORDS: Lamentations, narrative, hope, memory, presence

\section{A A TALE TO TELL}

The arc of a story takes the hearer on a journey with the characters, from stasis, through rising action, to a climax or crisis turning point, then through falling action to its final arrival at a resolution in which those characters, having experienced change, are transformed by it. A tragic hero, for example, may fall from greatness and be destroyed by a fatal flaw as she journeys through the story arc or a mundane and unassuming journeyman may uncover hidden strengths and surmount mammoth obstacles. The keys to moving the story along are the crisis that acts as a catalyst for the turning point and the resulting transformation that is discovered and owned at the story's resolution. Daughter Zion in Lamentations has already suffered catastrophic loss as the story opens, so that a return to stability, whether through a change of circumstances or a shift in her understanding of God or a relinquishing of her closely held understanding of the world, is called for.

As we move through the book of Lamentations the pressure to relieve the suffering of the exiles is compelling; preferably with the hoped for 'happy ending', but failing that at least with a renewed sense of meaning, whether because God's forgiveness is finally forthcoming or because his abandonment of his people becomes irrevocable. But we find the most obvious candidate for such

* Submitted: 14/08/2018; peer-reviewed: 21/09/2018; accepted: 27/11/2018. Scott Ellington, "De-Centering Lamentations: A Crisis of Hope, of Memory, and of Continued Presence," Old Testament Essays 31 no. 3 (2018): 494-505. https://doi. org/10.17159/2312-3621/2018/v31n3a5. 
an apparent resolution not at the end of the book where we would expect it, in chapter five, but rather at its centre.

But this I call to mind.

and therefore I have hope:

the steadfast love of the LORD never ceases, his mercies never come to an end;

they are new every morning;

great is your faithfulness. 1

There, indeed, is the storybook ending that should provide the narrative's dénouement. But the hitch is that the needed resolution has wandered from its accustomed place, finding its way to the centre of the story.

The ending to the book of Lamentations, in contrast, forestalls the expected closure, leaving the hearer hanging and the future of Israel's relationship with God anything but certain.

Restore us to yourself, O LORD, that we may be restored;

renew our days as of old -

unless you have utterly rejected us,

and are angry with use beyond measure. 2

Some translations, such as the Authorized Version, present even more starkly the apparent conflict that is still at play at the book's close by rendering verse 22 as a clear declaration.

Turn thou us unto thee, O LORD, and we shall be turned;

renew our days as of old.

But thou hast utterly rejected us;

thou art very wroth against us.

Other translations, such as the New Living Translation, emphasize the openness and uncertainty of the ending by translating verse 22 as an interrogative.

Restore us, O LORD, and bring us back to you again!

Give us back the joys we once had!

Or have you utterly rejected us?

Are you angry with us still?

But regardless of the choice made in translating the final verses of the book, they seem to lack the needed resolution that would place limits on Israel's suffering and bring an end to God's silence. Tod Linafelt capitalizes on this open-

1 Lam. 3:21-23. Unless otherwise indicated, the New Revised Standard Version will be used in citing the biblical text.

2 Lam. 5:21-22. 
endedness arguing that the book concludes with a "willful non-ending". $3 \mathrm{He}$ contends that the closing is an incomplete "if . . then . .." statement; a protasis with the apodosis unstated but nevertheless implied.

Take us back, O LORD, to yourself and we will come back.

Renew our days as of old.

For if you truly have rejected us, raging bitterly against us -

He concludes that the lack of completion is intentional and that "By arresting the movement from an 'if' to a 'then,' the incomplete clause allows the reader, for a moment, to imagine the possibility of a different 'then,' and therefore a different future."4 This suggests that the nature of the transformation taking place in the characters as the result of their experience of exile is held open by the poet(s) of Lamentations. Space is created to consider the unthinkable, that God's relationship with Israel has changed fundamentally and irrevocably. Certainly, whether or not Linafelt's thesis is accepted, by the end of the book Zion's future remains uncertain and God's silence persists, so that it concludes with invitation and expectation rather than closure.

In this study I will consider the theses a) that the book of Lamentations does, in fact, follow a basic story arc, b) that chapter three provides not the resolution for the story with a return to stasis, but instead acts as the crisis that initiates a turning point providing the catalyst for transformation, and c) that the narrative of transformation in chapter five, precisely in its open-endedness, supplies the theological focal point for the book.

\section{B CHANGE COMES IN THE END}

Some scholars have suggested that Lamentations is not a coherent narrative, that it does not tell a lucid story. ${ }^{5}$ Benjamin Morse, for example, suggests that Lamentations can best be understood as a montage, a series of thematically related images that evoke an emotional connection, but which do not evidence a linear story development. ${ }^{6}$ But while the notion of non-linear images capitalizes on poetry's ability to evoke powerful emotion and a sense of shared experience, nevertheless this understanding does not fully appreciate the verbal interplay

3 Tod Linafelt, "The Refusal of a Conclusion in the Book of Lamentation," Journal of Biblical Literature. 120/2 (Sum 2001): 343.

4 Linafelt, "Refusal of a Conclusion", 343.

5 Claus Westermann discusses the essential change in scholarly opinion from viewing the poems in Lamentations as independent compositions in older scholarship to the more recent trend toward considering the unifying elements of the poems in their present form. Lamentations: Issues and Interpretation, translated by Charles Muenchow (Minneapolis: Fortress Press, 1994), 58, 87-88.

6 Benjamin Morse, "The Lamentations Project: Biblical Mourning Through Modern Montage" Journal for the Study of the Old Testament 28/1 (2003): 119. 
between the different characters presented, the literary devices employed in order to affect change, and the forward movement from dirge to lament to a unified call for God to respond that is achieved by the storyteller.

A number of Lamentations scholars have focused on the varied voices brought together in the book and the ways that their interplay seeks to explore and explain the destruction of Jerusalem and the plight of the exiles. (Lanahan, Nancy Lee, Mandalfo, O'Connor, Nguyen) As few as three and as many as nine voices have been proposed, ${ }^{7}$ but in the discussion that follows I will opt for four voices; A Prophetic voice that encounters and describes the destruction of Zion, Daughter Zion who both expresses her anguish and lobbies God for relief, a male Refugee from the destruction of Zion who at least in part provides a countertestimony to that of Daughter Zion, and the larger Community that mobilizes the prayer of lament it addressing God. This dialogue between diverse and, at times, divergent voices and the various tensions that it sharpens fuel the theological heart of the book's message, so that the theological stance taken by Lamentations is created and sustained by its dissonant voices and the story that they tell together.

As I've suggested above, there is a long tradition among commentators of looking to the centre of Lamentations to find resolution and meaning (Gottwald, Boda, Archie Lee, Allen). ${ }^{8}$ Reasons for this conviction include the more hopeful perspective adopted by the male figure in the middle of the chapter, that chapter's greater length and thus more demanding acrostic form, and the assumption that Lamentations exhibits a chiastic form in order to highlight the theological conviction of the book by placing it at the center.

A number of scholars, though, have pointed to the limitations of this view. Tod Linafelt, for instance, is suspicious of the assumptions underpinning such a reading.

I ended up arguing that there are three primary reasons for the movement away [in chapter three] from Zion and her children: (1) a masculine bias toward the male figure in Lam 3; (2) a Christian bias toward the suffering of this male figure, based on a perceived similarity to the figure of Jesus Christ (passages from Lam 3 are

7 Robin A. Parry, Lamentations (Grand Rapids: William B. Eerdman's Publishing Company, 2010), 12.

8 Heath Thomas provides examples of commentators who present a variety of arguments to support this assumption, Poetry and Theology in the Book of Lamentations: The Aesthetics of an Open Text (Sheffield: Sheffield Phoenix Press, 2013), (5-6), while Walter Bouzard offers an extensive survey of scholars holding this view, "Boxed by the Orthodox: The Function of Lamentations 3:22-39 in the Message of the Book," in Why? ... How Long?: Studies on Voice(s) of Lamentation Rotted in Biblical Hebrew Poetry, edited by LeAnn Snow Flesher et al. (New York: Bloomsbury, 2014), note 3, 69. 
traditionally read on Good Friday); and (3) a broader emphasis in both Christian and Jewish interpretation on reconciliation with God rather than confrontation, and the suffering man of Lam 3 fits this emphasis much more easily than the demanding, challenging voice of Zion in Lam 1 and 2.9

Additionally, Kathleen O'Connor points out the forced nature of the argument for symmetry that appears to point the reader to chapter three as the chiastic centre of the book for its climax.

Despite its midpoint location, however, chapter 3 is not bordered by symmetrically composed poems to clinch such an interpretive decision. The poems that precede chapter 3 do not match the poems that follow it in length and form. Instead chapters 4 and 5 grow shorter, and the acrostic form disappears altogether in chapter 5.10

Given the use of acrostic and chapter length to punctuate the message, then, it is the breakdown of that structure that is intended to draw the ear of the hearer onward from the story's centre to its pregnant ending. The effect of this is to underscore the ongoing silence of God and to make most acute the question with which the community presents him. As O'Connor points out, "There is no response from God in this book. There is only the blind God, the missing voice that hovers over the entire book. Lamentations is about absence." 11 For O'Connor such silence is necessary. "Had the poets of Lamentations given a speech to God, God's words would silence debate; the struggle with pain would come to closure prematurely." 12 Silence, though, should not be mistaken for absence. It is the very nature of the lament prayer to press into God's silence and were God truly absence such speech would devolve into dirge, the articulation of pain without the expectation of relief, or would cease altogether. It is God's silence, then, that the characters in Lamentations seek to break and it is the question of his continued presence with the community toward which the poet(s) lead their hearers.

\section{THIS I CALL TO MIND}

Two features in Lamentations suggest an unfolding story arc that progresses linearly to arrive, at the end of chapter five, at a crossroads poised for change.

9 Tod Linafelt, "Surviving Lamentations (One More Time)," in Lamentations in Ancient and Contemporary Cultural Contexts, edited by Nancy C. Lee and Carleen Mandolfo (Atlanta: Society of Biblical Literature, 2008), 62.

10 "The Book of Lamentations: Introduction, Commentary, and Reflections." in The New Interpreter's Bible: A Commentary in Twelve Volumes: Isaiah-Ezekiel, Vol. 6, edited by Leander E. Keck et al. (Nashville: Abingdon Press, 2001), 1021.

11 O'Connor, "Book of Lamentations", 1071.

12 "Voices Arguing about Meaning," in Lamentations in Ancient and Contemporary Cultural Contexts, edited by Nancy C. Lee and Carleen Mandolfo (Atlanta: Society of Biblical Literature, 2008), 28. 
First, the crisis point is reached and the crisis precipitated by an act of remembrance in chapter three that reconnects the community with its formative story as the Refuge "remembers" the nation's birth narrative. Second, there is a progression as the book unfolds; a drawing together of Prophet and Community around stricken Zion. This is accompanied by a change of language from the articulation of pain in dirges to a call for relief in laments that both heighten the community's expectation and punctuate the divine silence. The mobilizing of the community in sustained lament in the final chapter of the story presses the questions of God's ongoing presence with his people and the continued existence of his covenant with them to the breaking point. With bated breath and an unfinished prayer that the people themselves cannot complete, the story awaits final resolution with God who will either break or perpetuate his silence.

Chapter three is pivotal to our understanding of the book not because it provides resolution, but rather because it introduces the elements that frame the crisis that is at the heart of the book's climax. More specifically, through an act of remembrance the Refugee in chapter three connects the suffering and loss of Daughter Zion with the presence and, indeed, the very name and nature of God. He remembers that:

The steadfast love of the LORD never ceases,

his mercies never come to an end;

they are new every morning;

great is his faithfulness ....

Although he causes grief he will have compassion

according to the abundance of his steadfast love. 13

The speaker evokes the memory of the covenant's foundation, with the threat of loss due to Israel's sin with the Golden Calf and the crisis of presence that resulted in Exodus 32-34, connecting it to the current crisis. ${ }^{14} \mathrm{He}$ calls to remembrance Yahweh's steadfast love (hesed; vv. 22, 32), faithfulness (emunah; v. 23), and his mercy/compassion (racham; v. 22, râcham; v. 32), pointing to the declaration of the divine name that provides the climax for this parallel story. ${ }^{15}$

The LORD, the LORD,

a God merciful (râcham) and gracious, slow to anger, and abounding in steadfast love (hesed) and faithfulness, keeping steadfast love (hesed) for the thousandth generation,

13 Lam. 3:21-22, 32.

14 A number of scholars have noted the connection of the Refugee's language in chapter three with the declaration of the divine name in Exodus 34:6-7, including Westermann, Bracke, Berlin, Allen, and Wright.

15 The story of the threatened loss of God's presence and possession of his chosen people in Ex. 32-34 is itself a counterweight to the description surrounding it of the design and building of the tabernacle, the visible symbol of God's covenant and presence with Israel, in Ex. 25-31 and 35-40. 
forgiving iniquity and transgression and sin,

yet by no means clearing the guilty,

but visiting the iniquity of the parents upon the children

and the children's children,

to the third and fourth generation. 16

The Refugee's claim, though, does not evoke the declaration of the divine name alone with its attributions of justice and mercy, but also the larger story contained in Exodus 32-34 where the newly formed covenant, together with the presence of Yahweh with his people, come under threat. Moses must petition for the people's very survival (Ex. 32:7-14) and for Yahweh's continued willingness to accept them as his own (Ex. 32:7, 11). Even when God repents his intention to destroy the people, Moses must nevertheless lobby for God's continued presence with his people. "And he said to him, 'If your presence will not go, do not carry us up from here. For how shall it be known that I have found favour in your sight, I and your people, unless you go with us? In this way, we shall be distinct, I and your people, from every people, on the face of the earth." (Ex. 33:15-16) The crisis point in Lamentations frames the question of God's continued presence among his people.

Frederick W. Dobbs-Allsopp argues that the contrast between the Refugee's affirmation in chapter three and the obvious failure of that claim to be realized in chapter five is ironic, that the Refugee's attestation provides the foil or frame over against and in contrast to the reality experienced by the exiles. ${ }^{17}$ The limitation of this view, though, is that it assumes an essential resignation and acceptance on the Community's part in chapter five, rather than a growing focus on the protest inherent in community lament. For Dobbs-Allsopp it is the articulation of the tragedy in itself that offers a measure of catharsis and healing. ${ }^{18}$ But the community lament does more than express pain, it protests divine forgetfulness and insists that only God's continued presence and covenant fidelity can make healing and restoration possible.

Adele Berlin and Dobbs-Allsopp both note parallels in language between Lamentations 3 and Psalm 77, a communal prayer that explores the nature of God's relationship with his people and the prospect that that relationship many, in fact, have changed. Berlin compares Lam. 3:18-21 with Ps. 77:7-8;19

Will the LORD spurn for ever, and never again be favourable?

16 Ex. 34:6-7.

17 "Tragedy, Tradition, and Theology in the Book of Lamentations," Journal for the Study of the Old Testament 74 (1997), 49-50.

18 Dobbs-Allsopp, “Tragedy, Tradition, and Theology", 58-59.

19 Adele Berlin, Lamentations: A Commentary (Louisville: Westminster John Knox Press, 2002), 92. 
Has his steadfast love ceased for ever?

Are his promises at an end for all time?

Dobbs-Allsopp notes a parallel between Lam. 3:21, 24 and the act of remembering Ps. 77:11-12;20

I will call to mind the deeds of the LORD;

I will remember your wonders of old.

I will meditate on all your works,

and muse on your mighty deeds.

Neither, though, calls attention the theological core of Ps. 77 which expresses the heart of the community's crisis; "And I say, 'It is my grief that the right hand of the Most High has changed."' (v. 10) And it is this fear which fuels the essential question being asked not by the Refugee in Lam. 3, who moves quickly to an assurance of being heard in Lam. 3:55-63, but by the Community in Lam. 5:21-22.

By the book's close this core affirmation of the Refugee remains a memory, attesting to the past but by no means guaranteeing the future, and it is not clear whether Yahweh continues to share that memory. With language characteristic of the genre, the community lament in chapter 5 opens "Remember, O LORD" (v. 1) and draws toward its finale with the accusation and demand "Why have you forgotten us completely? Why have you forsaken us these many days?" (v. 20) The Refugee's attestation in chapter 3, far from resolving the crisis presses it to the wall, demanding to know whether Yahweh will break silence and renew his presence with the community of faith. The Community of faith may remember and continue to own the Exodus story, but it remains to be seen whether or not Yahweh will do so.

\section{NO LONGER ALONE}

While Lamentations is by no means a simple, straightforward narrative telling a clear linear tale, nevertheless there is a progression of the story line and coming together of the characters in the poems as they are now organized, so that the book as a whole tells a story. This can be seen in two movements; the shift in genre from dirge to lament and the move from isolation to community. The poems evolve from the expression of anguish typical of dirges to language of protest found in lament prayers that demands change. And the isolation of Daughter Zion and the Refugee are relieved as they are linked to the Prophet and are once more counted among the Community who joins them in prayer and protest.

Though the genres of dirge and lament are somewhat mixed throughout the book, there is a basic movement from dirge in the beginning to lament as the

20 F. W. Dobbs-Allsopp, Lamentations (Louisville: John Knox Press, 2002), 116. 
book concludes. Mark Boda, for example, contends that Lamentations 1, 2, and 4 are city dirges, while 3 is an individual lament and 5 is a communal lament. ${ }^{21}$ Certainly dirges, with their offering of desolation and anguish, are far from passive, with shame, protest, and even accusation implied. But prayers of lament are much more explicit in their use of the language of protest that challenges and seeks change, pressing God for response. As Westermann puts it, "The dirge looks to the past; the plaintive lament looks to the future." 22 It is significant that both the orthodox testimony of the Refugee and the counter-testimony of the Community of faith adopt the prayer of lament in addressing Zion's crisis and that a number of parallels can be drawn between Lamentations and the tradition of lament prayers in the Psalter.

There is also a movement throughout the book from isolation toward community that can be seen first of all in the exchange between Daughter Zion and the Prophet in the first two chapters. In chapter one the Prophet is essentially a spectator, talking about Zion's sufferings, "How lonely sits the city that once was full of people! How like a widow she has become, she that was great among the nations!" Daughter Zion, on the other hand, speaks of her suffering and addresses herself to an unresponsive God. "O LORD, look at my affliction for the enemy has triumphed!" (v. 9b) And to passersby, "Look and see if there is any sorrow like my sorrow, which was brought upon me, which the LORD inflicted on the day of his fierce anger." (v. 12b) In chapter two, though, the two voices are drawn together in common cause as the Prophet's voice first turns to lament; "My eyes are spent with weeping; my stomach churns; my bile is poured out on the ground because of the destruction of my people" (v. 11a), and then urges Daughter Zion to renew her own prayers; "Cry aloud to the Lord! O wall of daughter Zion! Let tears stream down like a torrent day and night! Give yourself no rest, your eyes no respite!" (v. 18) As the poems progress, the Prophet loses all detachment and distance, entering into Zion's pain and taking up her lament.

In spite of the Refugee's hopeful words, Daughter Zion's grief in chapter four is not deflected; "For the chastisement of my people has been greater than the punishment of Sodom, which was overthrown in a moment, though no hand was laid on it" (v. 6), and she is joined beginning in verse 17 by the voice of the congregation; "Our eyes filled, ever watching vainly for help; we were watching eagerly for a nation that could not save." The cry of Daughter Zion has blazed the trail, inciting the compassion and enlivening the prayers first of the Prophet

21 Mark J. Boda, "Lamentations 1, Book of," in Dictionary of the Old Testament: Wisdom, Poetry \& Writings, edited by Tremper Longman and Peter Enns (Downers Grove: IVP Academic, 2008), 401. My own argument is not that the book of Lamentations as a whole moves cleanly from city dirge to individual and community lament, but rather that there is a general progression with dirge dominating the opening chapters and community lament the book's conclusion.

22 Westermann, Lamentations, 95. 
and then of the Community as a whole. She has converted both to her cause and provided the catalyst for the people to renew their dialogue in the face of God's silence.

Like a song that begins with a lone voice, but then swells to include the full chorus, in chapter five the Community that has suffered so much loss has been given voice, not simply to express their pain, but to engage in the type of prayer most calculated to move God. The chapter opens with imperatives typical of lament prayer as God is called upon to "remember," "look," and "see" in the opening verse. Verses 2-18 contain an extended catalogue of their woe and suffering. The turn in verse 19 is reminiscent of Psalm 102. Lamentations 5:19, "But you, O LORD, reign for ever; your throne endures to all generations", echoes the claim in Psalm 102:12, "But you, O LORD, are enthroned for ever, your name endures to all generations". This is followed in Ps. 102 with the assertion that everything else in creation is temporal and evanescent. The security for God's people, though, is found not in their fragile mortality or in finite creation, but in their ongoing relationship with him as they dwell in Yahweh's presence; "The children of your servants shall live secure; their offspring shall be established in your presence." (v. 28) And it is that presence and the continuation of that relationship which is Israel's hope for a future in Lamentations. The question is not whether God will endure, but whether desolate Zion will continue in his presence.

Lamentations tells the story of a journey to find a voice for a people confounded by loss. As the story opens Daughter Zion has no slowness of speech. She has her voice and is able from the beginning both to express anguish and to speak boldly to the one who has orchestrated her desolation. Ironically, it is the Prophet who struggles initially to find words that do more than merely describe from a distance, words that share in and own Zion's devastation. The Refugee joins readily with Daughter Zion's expressions of suffering, adding the memories that both give Zion her sense of identity and make more profound her misery by making unavoidable the contrast between what once was and what now is. But there is a 'stepping back' as well on the part of the Refugee, as he claims an assurance of being heard by God, when such an assurance is as yet far from certain. Such memories, far from allowing Daughter Zion to join in the Refugee's confidence of being heard (3:56-63), plunge her into renewed despair and it is her steadfastness and unwillingness to deny her experience that draws in and finally gives voice to the Community of faith. Because lament prayers are addressed to God, they are by their nature incomplete as long as they remain unanswered. A dirge requires no response, but laments ultimately force a transition. Either Yahweh will break silence to remember, to look, to see, or he will remain silent and withdraw his presence, taking from Israel finally their sense of self and place. It is God, one way or the other, who finally will conclude the story. 


\section{BIBLIOGRAPHY}

Allen, Leslie C. A Liturgy of Grief: A Pastoral Commentary on Lamentations. Grand Rapids: Baker Academic, 2011.

Berlin, Adele. Lamentations: A Commentary. Louisville: Westminster John Knox Press, 2002.

Boda, Mark J. "Lamentations 1, Book of." Pages 399-410 in Dictionary of the Old Testament: Wisdom, Poetry \& Writings. Edited by Tremper Longman and Peter Enns. Downers Grove: IVP Academic, 2008.

Bouzard, Walter C. "Boxed by the Orthodox: The Function of Lamentations 3:22-39 in the Message of the Book." Pages 68-82 in Why? ... How Long?: Studies on Vioce(s) of Lamentation Rotted in Biblical Hebrew Poetry. Edited by LeAnn Snow Flesher et al. New York: Bloomsbury, 2014.

Bracke, John M. Jeremiah 30-52 and Lamentations. Louisville: Westminster John Knox Press, 2000.

Dobbs-Allsopp, F. W. Lamentations. Louisville: John Knox Press, 2002. . "Tragedy, Tradition, and Theology in the Book of Lamentations." Journal for the Study of the Old Testament 74 (1997): 29-60. https://doi.org/10.1177/ 030908929702207402

Gottwald, N. K. "Lamentations, Book of." Pages 61-63 in The Interpreter's Dictionary of the Bible: An Illustrated Encyclopedia, K-Q. Edited by George Buttrick et al. Nashville: Abingdon Press, 1962.

Lanahan, William F. "The Speaking Voice in the Book of Lamentations." Journal of Biblical Literature, 93/1 (March, 1974): 41-49. https://doi.org/10.2307/3263864

Lee, Archie C. C. "Lamentations, Book of." Pages 565-568 in The New Interpreter's Dictionary of the Bible, I - Ma, vol. 3. Edited by Katharine Sakenfeld et al. Nashville: Abingdon Press, 2008.

Lee, Nancy C. The Singers of Lamentations: Cities under Siege, from Ur to Jerusalem to Sarahevo. Leiden: Brill, 2002.

Linafelt, Tod. "Surviving Lamentations (One More Time)." Pages 57-63 in Lamentations in Ancient and Contemporary Cultural Contexts. Edited by Nancy C. Lee and Carleen Mandolfo. Atlanta: Society of Biblical Literature, 2008. "The Refusal of a Conclusion in the Book of Lamentation." Journal of Biblical Literature. 120/2 (Sum 2001): 340-343.

Mandolfo, Carleen R. Daughter Zion Talks Back to the Prophets: A Dialogic Theology of the Book of Lamentations. Atlanta: Society of Biblical Literature, 2007.

Morse, Benjamin. "The Lamentations Project: Biblical Mourning through Modern Montage." Journal for the Study of the Old Testament 28/1 (2003): 113-27. https://doi.org/10.1177/030908920302800106

Nguyen, Kim Lan. Chorus in the Dark: The Voices of the Book of Lamentations. Sheffield, England: Sheffield Phoenix Press, 2013.

O'Connor, Kathleen M. "Voices Arguing about Meaning." Pages 27-32 in Lamentations in Ancient and Contemporary Cultural Contexts. Edited by Nancy C. Lee and Carleen Mandolfo. Atlanta: Society of Biblical Literature, 2008. . "The Book of Lamentations: Introduction, Commentary, and Reflections." Pages 1011-1072 in The New Interpreter's Bible: A Commentary in Twelve Volumes: Isaiah-Ezekiel, Vol. 6. Edited by Leander E. Keck et al. Nashville: Abingdon Press, 2001. 
Ellington, "De-Centering Lamentations," OTE 31/3 (2018): 494-505 505

Parry, Robin A. Lamentations. Grand Rapids: William B. Eerdman's Publishing Company, 2010.

Thomas, Heath A. Poetry and Theology in the Book of Lamentations: The Aesthetics of an Open Text. Sheffield: Sheffield Phoenix Press, 2013.

Westermann, Claus. Lamentations: Issues and Interpretation. Translated by Charles Muenchow. Minneapolis: Fortress Press, 1994.

Wright, Christopher J. H. The Message of Lamentations. Downers Grove: IVP Academic, 2015.

Scott Ellington, Professor of Christian Ministries at Emmanuel College in Franklin Springs, Georgia; Email: sellington100@aol.com. 